\title{
Kinome profiling of BLV-induced ovine leukemia: an approach for identifying altered signaling pathways associated with oncogenesis
}

\author{
Anne Van den Broeke ${ }^{1 *}$, Ryan Arsenault ${ }^{2}$, Nicolas Rosewick${ }^{1}, Y_{\text {vette Cleuter }}{ }^{1}$, Philippe Martiat ${ }^{1}$, Arsène Burny ${ }^{1}$, \\ Scott Napper ${ }^{2}$, Philip Griebel ${ }^{2}$
}

From 15th International Conference on Human Retroviruses: HTLV and Related Viruses

Leuven and Gembloux, Belgium. 5-8 June 2011

Transcriptome and miRnome information will likely be of significant value to our elucidation of the molecular mechanisms that govern cell transformation. However, an equally, if not more important goal, is to define those proteins that participate in signaling pathways that ultimately control cell fate.

Bovine Leukemia Virus (BLV), a delta-retrovirus closely related to HTLV-1, is associated with B-cell leukemia in sheep. We have employed kinome arrays which contain ovine peptide substrates selected to target known phosphorylation sites in proteins regulating key cell signaling pathways. Our data provide a quantitative measure of the phosphorylation activity of 300 kinases. We found significant changes in phosphorylation patterns of primary ovine leukemia/lymphoma versus normal B-cells. Pathway analysis tools revealed changes in proteins playing a major role in signaling cascades that determine cell-cycle entry, proliferation, survival and differentiation. Interestingly, analysis of cultured transformed B-cell lines suggested cell signaling events that characterize primary cancer cells were not conserved in vitro. Using NOD-Scid-Gamma immunodeficient mice and SC injection of ovine transformed B cell lines generated in vitro, we asked if transformed B-cells grown in mice would reflect the initial in vivo kinome profile identified in leukemic sheep. Finally, a priority identified for defining the rigour of our dataset was kinome analysis of an increased number of normal B-cells to provide an estimate of reference kinome diversity in an outbred population. Altogether, these investigations will provide

\footnotetext{
* Correspondence: anne.vandenbroeke@bordet.be

'Laboratory of Experimental Hematology, Institut Jules Bordet, Université

Libre de Bruxelles (ULB), 1000 Brussels, Belgium

Full list of author information is available at the end of the article
}

a critical analysis of the utility of kinome arrays as a technology to analyze oncogenesis, identify therapeutic targets, and select potential cancer biomarkers.

\section{Author details}

'Laboratory of Experimental Hematology, Institut Jules Bordet, Université Libre de Bruxelles (ULB), 1000 Brussels, Belgium. ${ }^{2}$ Pathogenomics, Vaccine and Infectious Disease Organization, University of Saskatchewan, Saskatoon, SK, Canada, S7N 5E3.

Published: 6 June 2011

doi:10.1186/1742-4690-8-S1-A16

Cite this article as: Van den Broeke et al:. Kinome profiling of BLVinduced ovine leukemia: an approach for identifying altered signaling pathways associated with oncogenesis. Retrovirology 2011 8(Suppl 1):A16.

Submit your next manuscript to BioMed Central and take full advantage of:

- Convenient online submission

- Thorough peer review

- No space constraints or color figure charges

- Immediate publication on acceptance

- Inclusion in PubMed, CAS, Scopus and Google Scholar

- Research which is freely available for redistribution 